Communication

\title{
Efficacy of Hormonal Growth Promoter Implants on the Performance of Grazing Steers of Different Breeds in Southern Chile
}

\author{
M. Jordana Rivero ${ }^{1,2}\left(\mathbb{D}\right.$, Luis Araya ${ }^{3}$, Marcelo Oyarzo ${ }^{4}{ }^{(}$, Andrew S. Cooke ${ }^{2}$, Sarah A. Morgan ${ }^{2} \mathbb{C}$ \\ and Veronica M. Merino ${ }^{5, *}$ (1)
}

1 Departamento de Ciencias Agropecuarias y Acuícolas, Facultad de Recursos Naturales, Universidad Católica de Temuco, Temuco 4780000, Chile; jordana.rivero-viera@rothamsted.ac.uk

2 Rothamsted Research, North Wyke, Okehampton EX20 2SB, UK; andrew.cooke@rothamsted.ac.uk (A.S.C.); sarah.morgan@rothamsted.ac.uk (S.A.M.)

3 Fundo "El Toro", Llanquihue 5610000, Chile; laraya@perezcruz.com

4 Prodesal Villarrica, Villarrica 4930000, Chile; marcelo.oyarzo.t@gmail.com

5 Faculty of Agriculture, Universidad de Concepción, P.O. Box 160-C, Concepción 4030000, Chile

* Correspondence: veronicamerino@udec.cl

Citation: Rivero, M.J.; Araya, L.; Oyarzo, M.; Cooke, A.S.; Morgan, S.A.; Merino, V.M. Efficacy of

Hormonal Growth Promoter Implants on the Performance of Grazing Steers of Different Breeds in Southern Chile. Sustainability 2021, 13, 9135. https:// doi.org/10.3390/su13169135

Academic Editor: Ana Kaić

Received: 23 July 2021

Accepted: 11 August 2021

Published: 15 August 2021

Publisher's Note: MDPI stays neutral with regard to jurisdictional claims in published maps and institutional affiliations.

Copyright: (c) 2021 by the authors. Licensee MDPI, Basel, Switzerland. This article is an open access article distributed under the terms and conditions of the Creative Commons Attribution (CC BY) license (https:/ / creativecommons.org/licenses/by/ $4.0 /)$.

\begin{abstract}
Increasing demands for land is necessitating the optimisation of grazing land used for livestock production. Hormonal growth promoter implants (HGPI) are widely used to improve cattle performance and thus land-use efficiency. However, there is limited information on their efficacy in grazing systems. Forty grazing steers, 10 of each breed (Angus, Hereford, Holstein, Overo Colorado), had growth rates monitored for 85 days after which half received HGPI and half continued as a control. Growth rates were monitored for an additional 61 days and performance between the groups compared. Implants had a significant impact on liveweight gain (LWG; $p=0.013$ ), and whilst breed $\operatorname{did} \operatorname{not}(p=0.65)$, there was an interaction effect of breed $\times$ treatment $(p=0.029)$. For three of the four breeds, the LWG was greater in the implant group (mean $+14.3 \%$ ). The exception was for Holstein steers which did not respond to the implant. In general, HGPI were found to be effective in increasing LWG of grazing cattle and thus has the potential to increase yield densities and relieve pressures of land use and competition. The efficacy may be affected by breed and other extraneous factors not covered in this study. Furthermore, the use of HGPI must be carefully considered in a wider context since its use might have secondary impacts.
\end{abstract}

Keywords: beef breeds; dairy breeds; anabolic implants; average daily gain; grazing

\section{Introduction}

Increasing demands for food have led to the intensification of beef production systems [1]. 'Sustainable intensification' of cattle production has been proposed as a route to reduce the environmental footprint of beef production systems through improvement in productive efficiency (resource use per unit of food output) [1]; which, in turn, could reduce GHG emissions of beef production associated with deforestation [2]. The use of production-enhancing technologies (PET, e.g., products altering nutrient partitioning toward milk production or lean muscle accretion) provides a clear opportunity to improve environmental sustainability. However, a dichotomy often exists between consumers desire for environmentally sustainable foods and a mistrust of technology use within food production [1]. It has been demonstrated that the removal of these technologies would increase production costs and reduce the global competitiveness of US beef, hence increasing resources and cumulatively increasing global GHG emissions through a deficit in US beef production being compensated for by increased production in less-efficient regions [3]. Therefore, these strategies must be assessed in their potential to contribute to increasing 
productivity, as a strategy to decrease GHG emissions, as well as in their potential impact to other dimensions of sustainability (e.g., social), since trade-offs may occur [4].

In order to meet the continually increasing global demand for beef, the beef cattle industry has been investing in new technologies such as hormonal growth promoter implants (HGPI). These implant products, both estrogenic and androgenic, are extensively used in beef cattle production to improve feed conversion efficiency and the growth rate of farm animals [5], largely in the Americas and Australasia. The use of HGPI have contributed to phenotypic improvements such as a $7 \%$ increase in the slaughter weight of steers and heifers ( $+30 \mathrm{~kg}$ and $+15 \mathrm{~kg}$, respectively) [5] and to the reduction of production costs by reducing the amount of feed required per unit of liveweight (LW) gained [6]. Furthermore, this improvement in production efficiency by HGPI use may reduce the overall GHG emissions from the sector by reducing the number of animals, time, and land required to produce equivalent quantities of beef [7].

Despite their productivity benefits, significant controversy surrounds the use of growth promoters for livestock due to concerns for human, animal, and environmental health [8]. Consequently, their use is heavily restricted or banned in many jurisdictions in Europe (Council Directive 96/22/EC, Council Directive 2003/74/EC; Council Directive 2008/97/EC) [9], though the extent of which is dependent on the class of growth promoter. Yet, a number of HGPIs such as trenbolone, zeranol, testosterone, or estradiol are officially allowed and are commonly used in beef cattle production in numerous countries (including the United States and Canada) [9]. According to a report by the World Organization for Animal Health [10], antimicrobial growth promoters were used in 45/155 (29\%) of the countries surveyed. Whilst no figure was provided for the use of HGPIs, it could be assumed that this figure is similar. Regarding the health implications to the animal, vaginal and rectal prolapses have been observed in heifers as an implant side effect [11], while the use of adrenocorticotropic hormone in dairy cattle has been found to increase milk cortisol concentrations by up to four times, suggesting it may act as a stressor [12]. However, such occurrences are rare and the evidence of association with HGPI has been scarcely reported in the scientific literature.

Active ingredients used in commercially available steroidal implant formulations are classified into three major categories of endogenously produced hormones: androgens, oestrogens, and progestins [13,14]; present in differing amounts and ratios in the final implant pellets [14] and formed from either natural (17 $\beta$ estradiol and progesterone) or synthetic compounds (trenbolone acetate and zeranol) [15]. Commercially-available HGPIs for use in beef cattle production have been classified according to their potency into low-, medium-, and high-potency implants [16] or coated and non-coated implants. Medium-potency implants (e.g., Revalor- $G^{\circledR}$ ) are recommended for grazing cattle, whereas high-potency implants are reserved for feedlot cattle $[9,10]$ fed at or near-maximum feed intake [17].

It has been established that animal performance varies widely across cattle breeds and types (including both dairy and beef breeds) [18]. In Chile, the dairy industry supplies approximately $80 \%$ of the animals for beef production, while the remainder are produced from beef cattle breeds [19]. Most are raised under grazing systems, with supplementation fed during the fattening phase (in winter and summer periods) in the form of conserved forages (as silage and/or hay) with or without a small amount of cereal grains [20]; which is mostly dependant on the geographical area in which the commercial farm is located [21].

The potential economic and environmental benefits and impacts of pasture-based beef systems compared to feedlot systems are widely understood [22]. However, despite the wide use of HGPIs in beef production in many countries, there is limited information available related to the growth performance of cattle implanted with HGPIs within grazing $[20,23,24]$ and preserved forage $[25,26]$ systems. The efficacy of HGPIs within these systems may differ from other systems (e.g., feedlots) due to differences in factors such as the environment and the feed type and provision, which may limit HGPI performance. 
Given the prevalence of hormonal growth promoters and their permissible use by many governments, it is essential that both the benefits and risks of these products are scientifically assessed. This includes studying the breadth of potential uses across different products, breeds, and production systems. There is currently limited research into the impact of HGPI within grazing beef systems, despite the prevalence of their use. Understanding the relationship between growth performance and animal genetics in response to HGPIs will allow for the objective assessment and optimisation of these tools in pasture-based systems. The aim of this study was to evaluate the efficacy of an HGPI $\left(\right.$ Revalor ${ }^{\circledR}$ ) on a mixed-breed herd of finishing steers under commercial grazing conditions in southern Chile.

\section{Materials and Methods}

The methodology used in this study followed the guidelines of the Committee for the Ethical Use of Animals in Experiments of the Universidad Católica de Temuco. The study was carried out at the "El Toro" commercial farm, in the Los Lagos region (Llanquihue province, $41^{\circ} 04^{\prime} \mathrm{S} 73^{\circ} 21^{\prime} \mathrm{W}$, Supplementary Material S1), southern Chile. Data collection started on 12 July 2016 and finished on 5 December 2016. Meteorological data was obtained from the Chilean National Meteorological Service (www.meteochile.gob.cl, accessed on 20 March 2017).

\subsection{Management of the Herd and Comparison Groups}

The farm typically acquires weaned, castrated, spring-born calves every autumn (March-May) when they are 200 days old, sourced from different breeding and dairy farms and purchased via livestock auctions. On arrival to the farm, all animals are dewormed (Dectomax (Elanco, Santiago, Chile) at $1 \mathrm{~mL} / 50 \mathrm{~kg} \mathrm{LW}$ ) and vaccinated against clostridia diseases (Visión 8 (Merck \& Co, Kenilworth, USA) at $2 \mathrm{~mL} /$ animal, plus a booster 21 days after arrival). The animals used in the present study $(n=40)$ were selected from the farms stock that was purchased in autumn 2016 comprising 10 calves from 4 different breeds: Aberdeen Angus (AA), Hereford (HD), European Holstein (FN or Chilean Frison Negro, a dairy breed), and Chilean Overo Colorado (OC or Deutsche Rotbunte, a dual-purpose breed). When steers reach 12-13 months old (October), they are usually implanted with an HGPI (Revalor G; trenbolone acetate $40 \mathrm{mg}$, $17 \beta$-estradiol $8 \mathrm{mg}$ ) 2 months before slaughter. However, for the purpose of this study, a subset of 20 steers ( 5 of each breed) did not receive HGPI in order to generate a control (non-implanted) group.

The data collection period spanned 146 days. The first 85 days were a pre-implant period. The implant was then applied, and the following 61 days were classified as the post-implant period. The assignment of HGPI was random within each breed group. Animals were weighed every 20 days throughout the study period. At the end of the study period (5 December), steers were sent to slaughter as part of the usual management of the farm.

\subsection{Pasture and Grazing Management}

Steers $(n=40)$ were managed under a strip grazing approach (electric front and back fences) on a sward comprised of Festuca arundinacea (Schreber), Dactylis glomerata L., and Lolium perenne $\mathrm{L}$. Snip samples (cut at $5 \mathrm{~cm}$ above ground) were taken twice from each paddock, once in August, and again in October. Samples were collected from a W transect and pooled across the paddocks to produce a composite sample ( $500 \mathrm{~g})$ per sampling month. Samples were dried in a forced-air oven at $60^{\circ} \mathrm{C}$ for $48 \mathrm{~h}$ to determine dry matter (DM) content. Samples were then ground to $2 \mathrm{~mm}$ and analysed via NIRS to estimate crude protein $(\mathrm{CP})$, neutral detergent fibre (NDF), acid detergent fibre (ADF), and metabolizable energy (ME). Steers were supplemented with hay made from the same pasture at a rate of $300 \mathrm{~g} / \mathrm{d}$ per animal for the duration of the assessment period.

All steers grazed as a single group in an area of approximately 8 ha of pasture. The size of the daily strip allocated for grazing was calculated assuming a forage DM intake of $2.5 \%$ 
of their LW in winter and 3.0\% in spring and using the daily herbage mass (HM) measured with a rising plate meter. Target HM pre- and post-grazing were 1800 and $1000 \mathrm{~kg} \mathrm{DM} / \mathrm{ha}$ (measured above $5 \mathrm{~cm}$ ), respectively.

\subsection{Statistical Analysis}

A complete randomised design was applied. In the pre-implant period (baseline), a two-way ANOVA with a factorial combination of breed (four levels; AA, HD, FN and OC) and implant (two levels; present and absent) was applied. Despite absence of HGPI in all animals during the baseline phase, the means were compared to assess the presence of any difference between groups in terms of starting age, LW and LWG. In the postimplant period, groups were compared using analysis of covariance, with breed and implant as categorical variables and age and LW at the beginning of the pre-implant phase as quantitative variables. The response variables were LWG and final LW. Fisher's least significant difference (LSD) was used for the statistical separation of means when the ANOVA results were significant $(p$-value $<0.05)$. All analyses were performed using Genstat 20 (CVSN International Ltd., Hemel Hempstead, UK).

\section{Results}

The mean temperature for October and November 2016 (post-implant period) were 10.3 and $12.9^{\circ} \mathrm{C}$, respectively. Table 1 shows the nutritional composition of the pasture grazed by steers in the pre- (August) and post- (October) assessment periods. Except for DM content and $\mathrm{CP}$, all the other nutritional components were similar between sampling dates.

Table 1. Nutritional composition of snip samples collected from the grazing paddocks in August and October 2016.

\begin{tabular}{ccc}
\hline Component $^{\mathbf{1}}$ & August & October \\
\hline DM (\%) & 12.2 & 16.3 \\
CP (\% DM) & 26.7 & 24.6 \\
ADF (\% DM) & 27.6 & 26.7 \\
NDF (\% DM) & 41.6 & 40.3 \\
ME (MJ/kg DM) & 11.8 & 12.0 \\
\hline
\end{tabular}

${ }^{1}$ DM: dry matter; CP: crude protein; ADF: acid detergent fibre; NDF: neutral detergent fibre; ME: metabolizable energy.

At the beginning of the pre-implant period, steers differed in age $(p=0.01)$ between the implant and the initial LW $(p<0.01)$ between breed groups (Table 2$)$. The Holstein (FN) steers were $27 \%$ heavier than the other breed types, and the steers to be implanted were 24 days older. However, the LWG pre-implant did not differ between implant group nor breed ( $p=0.07$ for breed and $p=0.173$ for implant groups) (Table 2).

Table 2. Steer age, initial liveweight (LW), and LW gained measured across 85 days prior to the application of the growth promoter implant (baseline) $(n=5)$.

\begin{tabular}{ccccccccccc}
\hline & \multicolumn{4}{c}{ Breed (B) } & \multicolumn{3}{c}{ Implant Group (I) } & s.e.d. & \multicolumn{2}{c}{$p$-Value } \\
\hline Variable & AA & HD & FN & OC & Yes & No & & B & I & B $\times$ I \\
\hline Age (d) & 299 & 297 & 300 & 293 & 309 & 285 & 17.9 & 0.957 & 0.01 & 0.283 \\
Initial LW $(\mathrm{kg})$ & $206 \mathrm{~b}$ & $208 \mathrm{~b}$ & $263 \mathrm{a}$ & $209 \mathrm{~b}$ & 224 & 218 & 14.4 & $<.001$ & 0.41 & 0.039 \\
LWG $(\mathrm{kg})$ & $87.9 \mathrm{~b}$ & $89.0 \mathrm{~b}$ & $114.8 \mathrm{a}$ & $95.8 \mathrm{~b}$ & 100.8 & 93.0 & 11.25 & 0.07 & 0.173 & 0.635 \\
\hline
\end{tabular}

AA: Aberdeen Angus; HD: Hereford; FN: Holstein (Chilean Frison Negro); OC: Chilean Overo Colorado (Deutsche Rotbunte); s.e.d.: standard error of the difference; LWG: LW gained. Means with differing lowercase letters are significantly different $(p<0.05)$.

The LW at the implant date was affected by the covariates age and initial LW $(p<0.01)$. Table 3 shows that neither breed nor implant group affected the adjusted LW at implant 
( $p=0.361$ for breed and $p=0.365$ for implant groups). Liveweight gained post-implant was not affected by the covariates used $(p=0.253)$.

Table 3. Liveweight (LW) at implant date, LW gained post-implant, and final LW after 61 days post-application of a growth promoter implant $(n=5)$.

\begin{tabular}{ccccccccccccc}
\hline & \multicolumn{3}{c}{} & \multicolumn{2}{c}{ Breed (B) } & \multicolumn{3}{c}{$\begin{array}{c}\text { Implant } \\
\text { Group (I) }\end{array}$} & s.e.d. & \multicolumn{3}{c}{$p$-Value } \\
\hline Variable & AA & HD & FN & OC & Yes & No & & B & I & B $\times$ I & Covariates \\
\hline LW at implant (kg) & 313 & 314 & 326 & 320 & 322 & 315 & 12.6 & 0.361 & 0.365 & 0.435 & $<0.001$ \\
LWG (kg) & 90.9 & 90.9 & 82.9 & 89.3 & 92.0 & 85.0 & 5.10 & 0.650 & 0.013 & 0.029 & 0.253 \\
Final LW (kg) & 404 & 405 & 409 & 410 & 413 & 400 & 30.0 & 0.730 & 0.096 & 0.116 & $<0.001$ \\
\hline
\end{tabular}

AA: Aberdeen Angus; HD: Hereford; FN: Holstein (Chilean Frison Negro); OC: Chilean Overo Colorado (Deutsche Rotbunte); s.e.d.: standard error of the difference; LWG: LW gained.

There was an interaction effect of breed $\times$ implant on the LWG (Table 3, $p=0.029$ ), which is further explained in Figure 1 (values not adjusted by covariates). The implanted steers of AA and OC breeds had far greater LWGs than the non-implanted steers of the same breed during the post-implant phase, whereas this effect was minimal for the HD steers and not present for the FN steers.

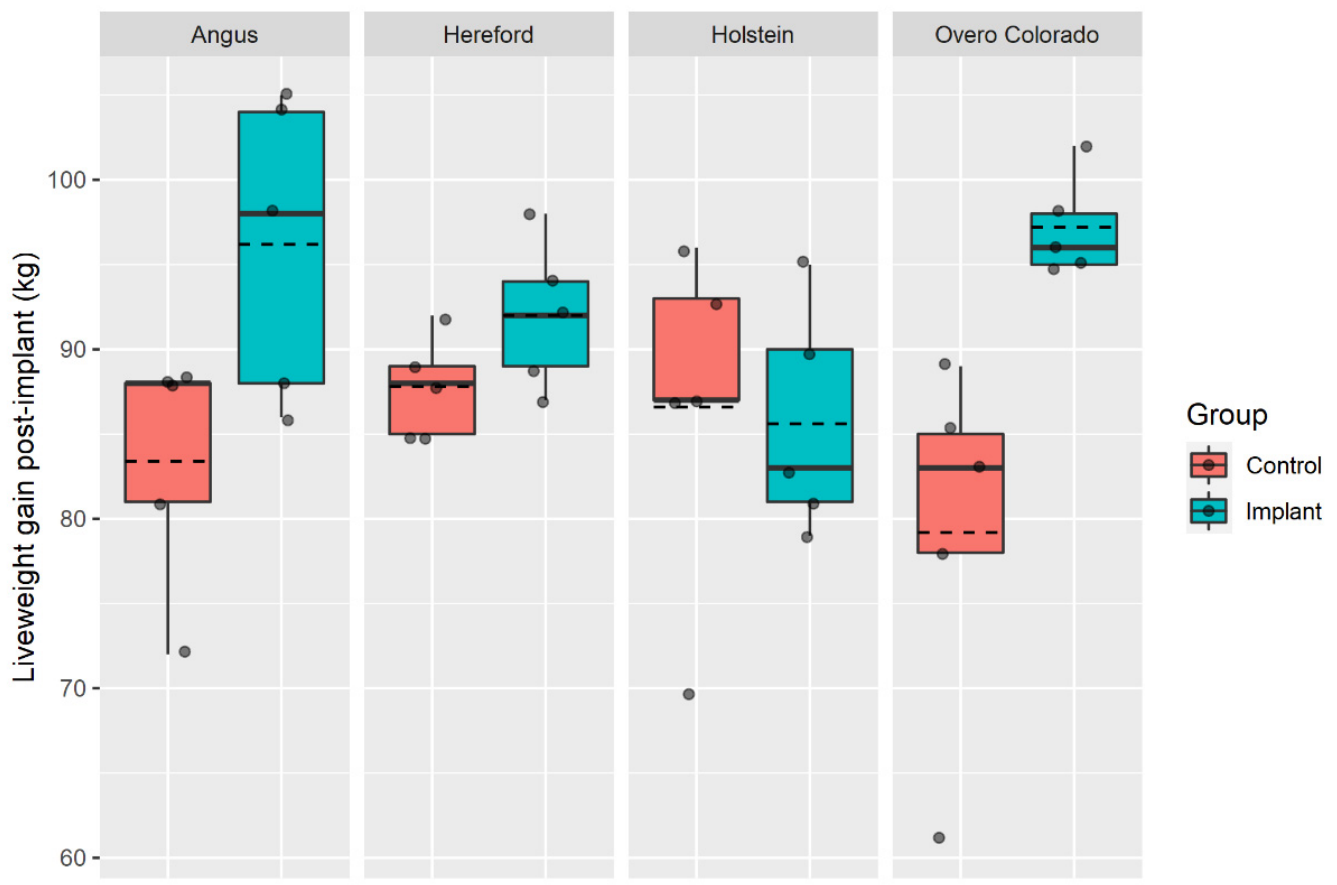

Figure 1. Total liveweight gained for the non-implanted (control) and implanted steers of four breeds during the 61-d post-implant period. Dashed lines represent mean. Figures created in ggplot2 [27].

Final LW at the end of the post-implant period were affected by the covariates used $(p<0.001)$ and tended to be affected by the implant $(p=0.096)$ (Table 3$)$. The adjusted final LW of the implanted steers was $13 \mathrm{~kg}$ greater than the non-implanted steers (413 vs. $400 \mathrm{~kg}$ ). The non-adjusted difference between means was $22 \mathrm{~kg}$.

\section{Discussion}

The mean final LW of steers that received a HGPI was $22 \mathrm{~kg}$ higher than the nonimplanted steers. Previous studies have shown varying responses in implanted steers. A recent study carried out in a similar location to the current study compared the effects of two different implant treatments, Revalor ${ }^{\circledR}$ and Synovex Plus ${ }^{\circledR}$ (200 mg of tren- 
bolone acetate (TBA) and $28 \mathrm{mg}$ of estradiol benzoate, respectively), in crossbreed steers (Hereford $\times$ Angus) under grazing conditions during spring. Implanted steers achieved a greater LWG, which was $39 \mathrm{~kg}$ more than the non-implanted steers $(101 \mathrm{~kg}$ vs. $62 \mathrm{~kg}$, respectively) over a 67-day period of grazing with no difference observed between the type of HGPI used [20]. This equated to an average daily gain (ADG) of $1.51 \mathrm{~kg} / \mathrm{d}$ for the implanted steers compared to $0.93 \mathrm{~kg} / \mathrm{d}$ for non-implanted steers. Similarly, Farney and Corrigan [28] reported a total LWG of $101 \mathrm{~kg}$ in stocker steers implanted with Revalor G (40 mg of TBA and $8 \mathrm{mg}$ of estradiol) during a 90-d grazing period, equating to an ADG of $1.12 \mathrm{~kg} / \mathrm{d}$.

Non-implanted cattle deposit fat earlier in the fattening period whereas implanted cattle continue to deposit protein, increasing their body size relative to non-implanted cattle at the same body composition [29]. The latter has been related to the fact that the HGPI extends the length of time that animals are in a phase of accelerated lean growth, allowing beef cattle to reach heavier LWs at finishing compared to non-implanted cattle [29]. Gill et al. [30] found that most of the LWG occurred in the last $60 \mathrm{~d}$ of grazing in implanted cattle, and therefore, the date on which the steers were implanted with Revalor ${ }^{\circledR}$ in the current study coincided with the expected period of greatest LWG for these animals.

Pasture chemical composition was comparable with previously reported values for high-quality pastures from southern Chile in spring [31,32], with high levels of $\mathrm{CP}$ and ME and low levels of NDF. The ADG recorded across all groups for the whole period was $1.27 \mathrm{~kg} / \mathrm{d}$ (186 kg LWG across $147 \mathrm{~d}$ ), which would suggest that the quality of the forage available was adequate for the grazing steers. It has been reported that in beef cattle grazing systems, the forage quality affects the implant LWG responses, with greater responses observed when pasture provides high-quality feed [33]. Considering the higher LWG observed during the post-implant period in the implanted steers compared to nonimplanted steers in the present study, we can presume that the quality of the spring pasture was adequate for initiating a positive response to HGPI. In Chile, ADG normally ranges between 0.8 to $1.5 \mathrm{~kg} / \mathrm{d}$ when cattle are fattened under grazing conditions during spring, and usually animals are slaughtered with a final LW between 418 to $472 \mathrm{~kg}$ [34]. Within the non-implanted group, the HD steers had the greatest ADG of $1.44 \mathrm{~kg} / \mathrm{d}$; suggesting that at the point of receiving the HGPI they might have already achieved much of their maximum growth potential under the grazing conditions $(1.51 \mathrm{~kg} / \mathrm{d})$ thus minimising the potential of HGPI to enhance the growth of these steers.

The breed $\times$ implant interaction led to a positive response of AA and OC steers to the HGPI (which grew between 15.3 and 22.3\% more than the non-implanted AA and OC steers, respectively); whereas the HD implanted steers only grew an additional $4.8 \%$, and FN did not respond to the implant. The growth phase the animal is in at the point of implant has the potential to influence the relative response to HGPI. In general, breeds that have the greatest potential for muscle growth show the greatest response to implants [35]. Thus, much of the LWG in response to implants containing TBA could be due to increased deposition of lean tissue in AA and OC cattle [36]. Holstein steers, as a dairy breed, have not been bred with the intention of high muscular growth, which may also have inhibited the potential of HGPI. Considering that the Holstein is a late-maturing breed [37], male Holstein calves transferred from Chilean dairy farms to produce beef are slaughtered at a relatively early age/growth stage in order to avoid production problems and unnecessary costs [38].

Growth performance varies between cattle breeds under similar management and age $[29,39]$, and therefore, the optimal slaughter age and weight can vary widely according to their genotype and rate of maturity. This study underlines the large differences in growth pattern seen between dairy-breed oriented (dairy breed and dual-purpose breeds) and specialized beef breeds, which was reflected in the LW recorded. As would be predicted from their large mature size, the FN (Holstein) steers were heavier than the other breeds. Conforming to breed classification based on their morphological traits, the FN breed belongs to the tall and heavy breed group with larger mature body size, an intermediate 
pelvis width and medium muscular development; whereas AA and HD are typical beef breeds characterized by their high musculature development with a wide pelvis and medium height [40]. In addition, Holstein cattle deposit a greater proportion of bone and muscle and a smaller proportion of fat in the carcass, unlike the more traditional beef breeds $[41,42]$. Thus, FN steers had higher body weights compared to the British beef (AA and HD) and OC steers.

Growth promoters remain a controversial means of improving livestock performance and are highly restricted or banned in many jurisdictions [43,44]. This is primarily due to animal welfare concerns [11,12], the potential for the passage of compounds into the human food chain [43], and, in the case of antimicrobial growth promoters, the risk of antimicrobial resistance [45-48]. Given the natural occurrence of many of their active ingredients within the human body, it is the concentration, not presence, which is important [8]. Commercially available steroidal implants have been developed with different carriers to target specific phases of beef production (e.g., cholesterol is the carrier of Revalor- $G^{\circledR}$ ), which results in a rapid spike in blood hormone concentrations after a few days of the implants administration that slowly dissipates as days go by [28]. This relatively short lifespan and the large size of beef cattle means that the bioaccumulation, development, and pathological effects on animal and human health are unlikely [28]. The labels of commercial HGPI used in cattle warn about the possibility of the occurrence of vagina-, recto-, and prepuce-prolapse, ventral edema, sunken loins, udder growth, and alterations in behavior, but the frequency of these symptoms are lower than $0.5 \%$ of the treated animals [49] and few studies exist that show an association of these with HGPIs [11]. A greater secondary effect of HGPIs on animal welfare is risk of heat stress driven by increased growth rates. However, this symptom is more likely in hot environments and feedlots [11].

The positive effect of HGPI use on the rate of liveweight gain of beef cattle on pasture or in a feedlot should be considered in the context of these risks and of public perception. The cost-benefit analysis (e.g., increased productivity vs. access to new markets) should be considered when making the decision either at the farm or at the country level on the use of HGPI as a production-enhancing technology. Therefore, further research is needed to ensure that comparisons among HGPI are based on both their productive and human and animal health impact to more compressive assess the sustainability of these implants.

\section{Conclusions}

The use of a growth promoter implant was shown to be effective in grazing steers of Angus and Chilean Overo Colorado breeds under commercial production conditions, increasing their LWG by around $19 \%$, and to a lesser extent in Hereford steers $(\sim 5 \%)$. However, the growth promoter implant showed no efficacy in Holstein steers with regard to growth rate. This might be due to the greater $\mathrm{LW}$ of these steers relative to the other breeds investigated in this study and/or an interaction of the HGPI with the dairy genetics of the Holstein breed.

Supplementary Materials: The following are available online at https://www.mdpi.com/article/10.339 0/su13169135/s1. Supplementary Material S1. Map of Chile with the location of the experimental farm.

Author Contributions: Conceptualization, L.A. and M.J.R.; methodology, L.A. and M.J.R.; formal analysis, M.J.R.; investigation, L.A. and M.O.; resources, L.A.; data curation, M.J.R.; visualisation, A.S.C.; writing—original draft preparation, V.M.M. and M.J.R.; writing—review and editing, S.A.M. and A.S.C.; supervision, M.J.R. All authors have read and agreed to the published version of the manuscript.

Funding: Support for the write-up of this work and data analysis was received by the Biotechnology and Biological Sciences Research Council (BBSRC) through the research program Soil to Nutrition (S2N; BBS/E/C/000I0320) at Rothamsted Research.

Institutional Review Board Statement: The methodology used in this study followed the guidelines of the Committee for the Ethical Use of Animals in Experiments of the Universidad Católica de Temuco. Ethical review and approval were waived for this study due to the data having been 
collected from a commercial farm operating within their normal boundaries (i.e., they routinely apply anabolic implants to their cattle), and no additional procedures were required for this specific study.

Data Availability Statement: Data is available as supplementary material.

Acknowledgments: We thank the owners of "El Toro" farm for their indispensable support on this study.

Conflicts of Interest: The authors declare no conflict of interest.

\section{References}

1. Capper, J.L.; Bauman, D.E. The role of productivity in improving the environmental sustainability of ruminant production systems. Annu. Rev. Anim. Biosci. 2013, 1, 469-489. [CrossRef] [PubMed]

2. Cederberg, C.; Persson, U.M.; Neovius, K.; Molander, S.; Clift, R. Including carbon emissions from deforestation in the carbon footprint of Brazilian beef. Environ. Sci. Technol. 2011, 45, 1773-1779. [CrossRef]

3. Capper, J.L.; Hayes, D.J. The environmental and economic impact of removing growth-enhancing technologies from U.S. beef production. J. Anim. Sci. 2012, 90, 3527-3537. [CrossRef]

4. Aboagye, I.A.; Cordeiro, M.R.C.; McAllister, T.A.; Ominski, K.H. Productivity-enhancing technologies. Can consumer choices affect the environmental footprint of beef? Sustainability 2021, 13, 1-19. [CrossRef]

5. Thompson, J.M.; McIntyre, B.M.; Tudor, G.D.; Pethick, D.W.; Polkinghorne, R.; Watson, R. Effects of hormonal growth promotants (HGP) on growth, carcass characteristics, the palatability of different muscles in the beef carcass and their interaction with aging. Aust. J. Exp. Agric. 2008, 48, 1405-1414. [CrossRef]

6. Webb, A.S.; Rogers, R.W.; Rude, B.J. Review: Androgenic, estrogenic, and combination implants: Production and meat quality in beef. Prof. Anim. Sci. 2002, 18, 103-106. [CrossRef]

7. Avery, A.; Avery, D. The Environmental Safety and Benefits of Growth Enhancing Pharmaceutical Technologies in Beef Production. Available online: https://www.thecattlesite.com/articles/1240/the-environmental-safety-and-benefits-of-growth-enhancingpharmaceutical-technologies-in-beef-production/ (accessed on 23 July 2021).

8. Jeong, S.-H.; Kang, D.; Lim, M.-W.; Kang, C.S.; Sung, H.J. Risk assessment of growth hormones and antimicrobial residues in meat. Toxicol. Res. 2010, 26, 301-313. [CrossRef]

9. Stella, R.; Dervilly-Pinel, G.; Bovo, D.; Mastrorilli, E.; Royer, A.-L.; Angeletti, R.; Le Bizec, B.; Biancotto, G. Metabolomics analysis of liver reveals profile disruption in bovines upon steroid treatment. Metabolomics 2017, 13, 80. [CrossRef]

10. OIE. Annual Report on Antimicrobial Agents Intended for Use in Animals; OIE: Paris, France, 2018.

11. Hunter, R.A. Hormonal growth promotant use in the Australian beef industry. Anim. Prod. Sci. 2010, 50, 637-659. [CrossRef]

12. Fox, L.; Butler, W.R.; Everett, R.W.; Natzke, R.P. Effect of adrenocorticotropin on milk and plasma cortisol and prolactin concentrations. J. Dairy Sci. 1981, 64, 1794-1803. [CrossRef]

13. Johnson, B.J.; Ribeiro, F.R.B.; Beckett, J.L. Application of growth technologies in enhancing food security and sustainability. Anim. Front. 2013, 3, 8-13. [CrossRef]

14. Smith, Z.K.; Johnson, B.J. Mechanisms of steroidal implants to improve beef cattle growth: A review. J. Appl. Anim. Res. 2020, 48, 133-141. [CrossRef]

15. Song, M.K.; Choi, S.H. Growth promoters and their effects on beed production-Review. Asian Australas. J. Anim. Sci. 2001, 14, 123-135. [CrossRef]

16. Johnson, B.; Beckett, J. Application of Growth Enhancing Compounds in Modern Beef Production—Executive Summary; American Meat Association: Champaign, IL, USA, 2014; pp. 1-15.

17. Birkelo, C.P. Pharmaceuticals, direct-fed microbials, and enzymes for enhancing growth and feed efficiency of beef. Vet. Clin. North Am. Food Anim. Pract. 2003, 19, 599-624. [CrossRef]

18. Albertí, P.; Panea, B.; Sañudo, C.; Olleta, J.L.; Ripoll, G.; Ertbjerg, P.; Christensen, M.; Gigli, S.; Failla, S.; Concetti, S.; et al. Live weight, body size and carcass characteristics of young bulls of fifteen European breeds. Livest. Sci. 2008, 114, 19-30. [CrossRef]

19. Goic, L. Descripción y perspectivas de la producción de carne bovina en Chile. Informe final. In Taller Internacional: Limitaciones y Perspectivas del Sector Cárnico Bovino en Chile y el Mercosur; Catrileo, A., Ed.; FAO, Universidad Mayor: Santiago de Chile, Chile, 2001; pp. 136-148.

20. Arias, R.; Santa-Cruz, C.; Velásquez, A. Effect of high potency growth implants on average daily gain of grass-fattened steers. Animals 2019, 9, 587. [CrossRef] [PubMed]

21. Morales, R.; Folch, C.; Iraira, S.; Teuber, N.; Realini, C.E. Nutritional quality of beef produced in Chile from different production systems. Chil. J. Agric. Res. 2012, 72, 80-86. [CrossRef]

22. Boody, G.; Vondracek, B.; Andow, D.A.; Krinke, M.; Westra, J.; Zimmerman, J.; Welle, P. Multifunctional agriculture in the United States. Bioscience 2005, 55, 27-38. [CrossRef]

23. Blasi, D.A.; Kuhl, G.L. Effects of Revalor- $\mathrm{G}^{\circledR}$, Ralgro ${ }^{\circledR}$, and Synovex- $\mathrm{H}^{\circledR}$ on the performance of stocker heifers grazing irrigated rye pasture. In Cattlemen's Day; Agricultural Experiment Station and Cooperative Extension Service, Kansas State University: Manhattan, KS, USA, 1998; pp. 126-128. 
24. Cleale, R.M.; Hilbig, D.R.; Short, T.H.; Sweiger, S.H.; Gallery, T. Effects of Synovex One Grass, Revalor-G, or Encore implants on performance of steers grazing for up to 200 days. Prof. Anim. Sci. 2018, 34, 192-201. [CrossRef]

25. Berthiaume, R.; Mandell, I.; Faucitano, L.; Lafrenière, C. Comparison of alternative beef production systems based on forage finishing or grain-forage diets with or without growth promotants: 1. Feedlot performance, carcass quality, and production costs. J. Anim. Sci. 2006, 84, 2168-2177. [CrossRef] [PubMed]

26. Faucitano, L.; Chouinard, P.Y.; Fortin, J.; Mandell, I.B.; Lafrenière, C.; Girard, C.L.; Berthiaume, R. Comparison of alternative beef production systems based on forage finishing or grain-forage diets with or without growth promotants: 2 . Meat quality, fatty acid composition, and overall palatability. J. Anim. Sci. 2008, 86, 1678-1689. [CrossRef]

27. Wickham, H. ggplot2: Elegant Graphics for Data Analysis; Springer: New York, NY, USA, 2016.

28. Farney, J.K.; Corrigan, M. Short Communication: Evaluation of 2 implants for growing steers grazing tall-grass prairie when using intensive early stocking. Appl. Anim. Sci. 2019, 35, 83-87. [CrossRef]

29. Guiroy, P.J.; Tedeschi, L.O.; Fox, D.G.; Hutcheson, J.P. The effects of implant strategy on finished body weight of beef cattle. J. Anim. Sci. 2002, 80, 1791-1800. [CrossRef]

30. Gill, D.R.; Smith, S.C.; Nicholas, W.; Montague, M.R. Performance of stocker steers implanted with Ralgro, Synovex-S or Revalor-G. In Animal Science Research Report; Agricultural Experiment Station, Oklahoma State University: Stillwater, OK, USA, 1995; pp. 163-166.

31. Merino, V.; Balocchi, O.; Pulido, R. Effect of daily herbage allowance restriction on pasture characteristics and milk production by grazing dairy cows in spring. Cienc. e Investig. Agrar. 2018, 45, 21-34. [CrossRef]

32. Rivero, M.J.; Balocchi, O.A.; Moscoso, C.J.; Siebald, J.A.; Neumann, F.L.; Meyer, D.; Lee, M.R.F. Does the "high sugar" trait of perennial ryegrass cultivars express under temperate climate conditions? Grass Forage Sci. 2019. [CrossRef] [PubMed]

33. Kuhl, G.L. Stocker cattle responses to implants. In Proceedings of the Symposium: Impact of Implants on Performance and Carcass Value of Beef Cattle; Oklahoma Agricultural Experiment Station: Stillwater, OK, USA, 1997; pp. 51-62.

34. Goic, L.; Iraira, S. Engorda en Pastoreo. In Producción y Manejo de Carne Bovina en Chile; Catrileo, A., Ed.; Instituto de Investigaciones Agropecuarias, Ministerio de Agricultura: Temuco, Chile, 2005; pp. 275-293.

35. Hayden, J.M.; Bergen, W.G.; Merkel, R.A. Skeletal muscle protein metabolism and serum growth hormone, insulin, and cortisol concentrations in growing steers implanted with estradiol-17 beta, trenbolone acetate, or estradiol-17 beta plus trenbolone acetate. J. Anim. Sci. 1992, 70, 2109-2119. [CrossRef]

36. Anderson, P.T. Trenbolone acetate as a growth promotant. Compend. Contin. Educ. Pract. Vet. 1991, $13,1179$.

37. Nogalski, Z.; Wielgosz-Groth, Z.; Purwin, C.; Nogalska, A.; Sobczuk-Szul, M.; Winarski, R.; Pogorzelska, P. The effect of slaughter weight and fattening intensity on changes in carcass fatness in young Holstein-Friesian bulls. Ital. J. Anim. Sci. 2014, 13, 66-72. [CrossRef]

38. Catrileo, A.; Morales, R.; Rojas, C.; Cancino, D. Beef production from dairy bulls under two different production systems and its effect on the fatty acid profile and beef quality. Chil. J. Agric. Res. 2014, 74, 366-370. [CrossRef]

39. Pesonen, M.; Honkavaara, M.; Huuskonen, A. Effect of breed on production, carcass traits and meat quality of aberdeen angus, limousin and aberdeen angus $\times$ limousin bulls offered a grass silage-grain-based diet. Agric. Food Sci. 2012, 21, 361-369. [CrossRef]

40. Piedrafita, J.; Quintanilla, R.; Sañudo, C.; Olleta, J.L.; Campo, M.M.; Panea, B.; Renand, G.; Turin, F.; Jabet, S.; Osoro, K.; et al. Carcass quality of 10 beef cattle breeds of the Southwest of Europe in their typical production systems. Livest. Prod. Sci. 2003, 82, 1-13. [CrossRef]

41. Dolezal, H.G.; Tatum, J.D.; Williams, F.L. Effects of feeder cattle frame size, muscle thickness, and age class on days fed, weight, and carcass composition. J. Anim. Sci. 1993, 71, 2975-2985. [CrossRef]

42. Owens, F.N.; Gill, D.G.; Secrist, D.S.; Coleman, S.W. Review of some aspects of growth and development of feedlot cattle. J. Anim. Sci. 1995, 73, 3152-3172. [CrossRef] [PubMed]

43. Elmajdoub, A.; Garbaj, A.; Abolghait, S.; El-Mahmoudy, A. Evaluation of boldenone as a growth promoter in broilers: Safety and meat quality aspects. J. Food Drug Anal. 2016, 24, 284-292. [CrossRef]

44. EFSA Opinion of the Scientific Panel on contaminants in the food chain (CONTAM) related to hormone residues in bovine meat and meat products. EFSA J. 2007, 510, 1-62.

45. Boerlin, P.; Wissing, A.; Aarestrup, F.M.; Frey, J.; Nicolet, J. Antimicrobial growth promoter ban and resistance to macrolides and vancomycin in enterococci from pigs. J. Clin. Microbiol. 2001, 39, 4193-4195. [CrossRef] [PubMed]

46. Bengtsson, B.; Wierup, M. Antimicrobial resistance in scandinavia after ban of antimicrobial growth promoters. Anim. Biotechnol. 2006, 17, 147-156. [CrossRef] [PubMed]

47. WHO. Impacts of Antimicrobial Growth Promotor Termination in Denmark; WHO: Foulum, Denmark, 2003.

48. Callaway, T.R.; Edrington, T.S.; Rychlik, J.L.; Genovese, K.J.; Poole, T.L.; Jung, Y.S.; Bischoff, K.M.; Anderson, R.C.; Nisbet, D.J. Ionophores: Their use as ruminant growth promotants and impact on food safety. Curr. Issues Intest. Microbiol. 2003, 4, 43-51.

49. Aroeira, C.N.; Feddern, V.; Gressler, V.; Contreras-Castillo, C.J.; Hopkins, D.L. A review on growth promoters still allowed in cattle and pig production. Livest. Sci. 2021, 247, 104464. [CrossRef] 